\title{
G. F. Parrot and Emperor Alexander I: Two Decades of Correspondence, Its Personal and Political Aspects
}

\author{
Andrei Andreev \\ Faculty of History, \\ Lomonosow Moscow State University \\ Lomonosowsky prospect, d. 27, korp. 4, \\ Moscow 119192, Russia \\ E-mail: andrv@hist.msu.ru
}

\begin{abstract}
At the center of this study lies an unusual historical phenomenon-a close friendship that linked at the beginning of the 19th century the Russian autocrat, Emperor Alexander I and the professor of the Dorpat University, George Friedrich Parrot. Evidence of this friendship is kept in their correspondence, amounting to more than 200 letters. This archival complex of documents had a difficult fate, which in many respects prevented its timely introduction into the scientific use. Meanwhile, these letters not only tell how the personal relations between Parrot and Alexander I developed, but also show the degree of influence that the professor wanted to exert on state affairs, especially in the field of public education, through his advice and conversations with the Emperor. Parrot himself quite unselfishly tried to direct his influence on strengthening the principles of liberal reforms in the Russian Empire. However, in practice, the implementation of his advice ran into a number of obstacles, one of which was Alexander's constant inclination to compromise, and it was not as great as Parrot himself would have liked.
\end{abstract}

Keywords: Alexander I, archives, autocracy, correspondence, Georg Friedrich Parrot, internal policy, public education, reforms, University of Dorpat 


\section{Introduction}

The correspondence between Professor Georg Friedrich Parrot (1767-1852) and Russian Emperor Alexander I (1777-1825, ruled since 1801) provides a unique example of confident relations which joined a ruler of a huge autocratic empire and one of his subjects who did not take advantage of the disposition of the monarch to his own profit but tried to use their connection to initiate important reforms and to improve the state of the whole country.

Alexander, unknown to the masses, established with the professor from Dorpat such a relationship which denied all the distance between them. Not only was Parrot granted the right (which he used very often) to write to the sovereign in the tone of not a subject but a friend, about anything he wanted-governmental, domestic, even cordial affairs; not only did he receive the most sincere letters from the Emperor, but also every time he came from Dorpat to St. Petersburg he went straight to the Tsar's office, where he remained alone with the royal host for hours. Alexander sought to acquire and strengthen the friendship with the modest scientist, often trusting him his secrets, both public and private. (Korf, 1861, p. 13)

Professor Parrot belonged to a long row of so called "young friends and supporters" of Emperor Alexander I at the beginning of the era of liberal reforms in Russia in the first decade of the 19th century. The Tsar needed those friends to discuss some important concepts of reforming the political and social system of the Russian Empire. One may name the members of the so-called Secret Committee (Neglasnyi Komitet)—Adam Czartoryski (1770-1861), Pavel Stroganov (17741817), Nicolai Novosiltzev (1761-1838), and Victor Kotschubei (1768-1834). This Secret Committee was not a formal organization but a circle of friends, based on the mutual confidence and on the similarity of the liberal principles they professed. It is worth emphasizing that Alexander I was not the leader of this circle, and that he, emperor and autocrat, allowed himself to be driven by his friends in this Secret Committee as they discussed the main political changes in the social and administrative system of Russia (Safonov, 1988, pp. 121125). These circumstances led some historians to a more general conclusionthat the friends could guide the Russian Emperor wherever they wanted and could immediately influence his decisions. However, this argument should be 
investigated thoroughly in each special case. ${ }^{1}$ It is also important to note that this Secret Committee existed only for a very limited period of time, less than three years, and the most fruitful time of their activity lasted only for about a year in 1801-1802, so after this term Alexander I was "free" from such direct influence.

There are more examples of the personal relations with the Russian Emperor which had a clear political dimension. For example, in March 1801, just a few weeks after Alexander's accession to the throne, a young official Vasily Karazin (1773-1842) submitted him a letter in which he proclaimed his hopes for liberal reforms and the affranchisement of serfs (Gracheva, 2012, pp. 38-40). Alexander I greeted his young supporter, allowed him to pay a visit to the palace any time he liked and de facto promoted Karazin to the role of the Emperor's trusted person in different governmental affairs, especially in the field of public education. These relations between Alexander I and Karazin strongly influenced the founding of the University in Kharkov and the beginning of the school reforms in Russia (Andreev, 2009, p. 376). But the period of their mutual confidence-also in the case of the circle of Secret Committee — did not last for long, ending definitely in the middle of 1803 .

Especially the Tsar's educator, a Swiss citizen Frédéric-César de La Harpe (1754-1838), was the person who maintained correspondence with the Tsar throughout no less than forty years. La Harpe started as Alexander's strict teacher and mentor, but soon became his close friend. They were united by the same liberal principles of the Enlightenment, but the peculiarity lies in the fact that it was La Harpe himself who instructed young Alexander in those principles. During the first years of Alexander's rule, his correspondence with La Harpe was very active and important, touching upon the main concepts and measures of reforming Russia - it is worth mentioning that the very idea to create the Ministry of Public Education belonged to La Harpe and was developed in several of his papers to Alexander I (Andreev, 2009, p. 359). The whole extent of this correspondence amounts to more than 300 letters and 100 of accompanying documents. ${ }^{2}$ It is a very informative historical source, which covers many crucial points of the rule of Alexander I, but (one may stress again) as in the case of other Alexander's trusted persons, the activity of this correspondence between the Tsar and his Swiss mentor diminished after several years of closeness, and the degree of their confidence became more and more uncertain.

1 Literature describing the personality and character of Emperor Alexander I, is immense, see, selectively, Shilder, 1898; Hartely, 1994; Rey, 2009; Arkhangelskii, 2012.

2 The complete commented edition of this correspondence, based on archival sources, was prepared recently in three volumes in Russian language in collaboration between Russian and Swiss historians (Andreev \& Tosato-Rigo, 2014; 2017a; 2017b). 
After this short preamble the role and significance of the personal relations between Professor Parrot and Alexander I can be revealed more clearly. Their correspondence amounts to more than 190 letters from Parrot and 38 letters or short notes from Alexander I (LVVA, 1802-1825). From the simple quantitative point of view it takes the second place in the epistolary of Alexander I, just after the volume of the papers of La Harpe. The beginning of the correspondence between Parrot and Alexander I also fell on the Tsar's first years of rule, and the problems of reforming Russia discussed in these occupied an important place. However, this correspondence is far from having been fully introduced into scientific use until now. Below, the contribution dwells upon three important questions: the first is the study of this correspondence as a historical source with its peculiar and sometimes dramatic fate; the second point discusses how those letters characterize the personal relations between Parrot and Alexander I; and the third-what could be concluded about the real extent of Parrot's influence upon Alexander's political measures and decisions.

\section{Source study}

As emphasized above, Parrot's contribution to Russian history, and especially to the history of Russian universities, is quite significant. Nonetheless, his figure has not been sufficiently developed in historiography. For the most part, he is known as a scientist, whereas his role in the history of higher education in the Russian Empire has not be fully revealed and has been overshadowed by his other contemporaries. In my opinion, the main reason could be the fact that the complex of sources referred to in this article, revealing the relationship of Parrot with the Russian authorities, have not been available to professional historians for a long time.

The correspondence between Parrot and Alexander I had a very peculiar or even strange (or at least, unobvious) historical path that has kept it from correct scientific use until now. To begin with, almost nothing has remained of the original letters, which contrasts starkly, for example, with the Tsar's correspondence with La Harpe, where almost all of the letters could be seen now in their original scripts. In the Moscow and St. Petersburg archives one could find only a few original writings of Parrot which were originally addressed to Alexander I, provided that they were discovered only by chance among other sets of documents (RGADA, 1824-1825; RGIA, 1803). While it was a common 
rule that after the emperor's death all the personal letters of his correspondents were sent back to the authors, and so was the case with La Harpe, Parrot did not receive his writings from the Winter Palace after Alexander's demise, and no obvious explanation was given to this fact. Thus, the question remains whether these letters were kept by Alexander I in his working study until the end of his life.

The main source of exploring Parrot's letters are the rough copies carefully conserved by the professor. At the age of eighty he began to prepare these texts for publication and, directly related to this purpose, he created a first detailed register of his letters. In this task Parrot was assisted by his adopted daughter Sophie, who married in 1836 Platon Andreevich Storch (1809-?), a man of letters from St. Petersburg. Sophie Storch also made a copy of the register after her father and copied the most valuable component of the whole collection-38 letters written by Alexander I by his own hand (LVVA, 1850s, pp. 171-174; LVVA, 1802-1825, no. 6, pp. 2-35). Immediately after the demise of her father, Sophie Storch continued to fulfil his will and wanted to present those letters to the general public. Her husband Platon Storch began to work on the detailed biography of Parrot. Their general plan was to publish the correspondence of Parrot and his royal friend together with some commentaries and a biographical study on Parrot (RGIA, 1855, pp. 1-2).

All these preparatory materials were submitted in 1855 to the new emperor, Alexander II, by mediation of the Minister of Court Count Vladimir Adlerberg (1791-1884). The Emperor gave the task to investigate these documents and determine whether it was possible to publish them or not to Baron Modest Korf (1800-1876), the famous Russian bibliographer and court historian, especially known for his huge biographic collection on Emperor Nicolas I. As an expert of the epoch, Korf was very excited to read the correspondence between Parrot and Alexander I and he reported to Alexander II that those letters gave completely new insight into the personality of Alexander I as well as into the nature of Russian autocratic rule as whole, making it more humane, warm-hearted and sentimental (GARF, 1855, pp. 1-50). But exactly these were the reasons why, according to Korf, this correspondence could not be published in whole extent. Korf advised the new Tsar to give permission only to the publication of Parrot's biography with some possible interpolations from his letters to Alexander I; all those interpolations must be subject to general censorship (RGIA, 1855, pp. 3-4). But the publication of the letters in full was prohibited and the collection returned into the hands of Sophie Storch, who was evidently not glad 
about this decision, because all further work on her father's biography stopped and this biography was never given to the world.

Unfortunately, there is no direct information about the exact fate of the collection after Sophie Storch regained possession of it, because of our sufficient lack of knowledge of her biography. We can only guess that her divorce from her husband played some role in this. Almost the only thing we know for a fact is that in November 1876 the collection was still in the hands of Sophie Storch or her relatives in Libau, Courland, because a second copy of Alexander's autographs was made there from the originals and later added to the whole collection (LVVA, 1802-1825, no. 6, pp. 29-35). But what happened next? Some archival traces lead to new puzzles. One of the most disturbing of them has to do with the question of what became of the original autographs of Alexander I. In the archival fund today there exists a detailed register of those autographs, made by Parrot himself, and two series of copies; and even a sheet of paper that served as a cover to the original letters and notes of Alexander I remains-but the documents themselves have disappeared, and were evidently withdrawn from the collection after 1876 .

The next reference point in the story of the Parrot's collection of documents is the last decade of the 19th century. In 1894, the German literary magazine Deutsche Revue published some chosen letters of Parrot to Alexander I together with some replies of the Emperor (Bienemann, 1894). They were presented by Friedrich Bienemann (1838-1903), a historian and journalist, born in Riga and at that time a professor at the University of Freiburg in Bresgau. He continued publishing several other letters of Parrot in 1890s, and in 1902 Bienemann concluded his work on the book entitled Emperor Alexander I and Professor Parrot, which contained many wide citations and narrations from the correspondence under discussion (Bienemann, 1902). It should be mentioned that Bienemann died a year later, and the bad state of his health regrettably influenced his work which in some places is not as clear as it should be for the first presentation of a high-ranked historical source (Diederichs, 1909). And there were two crucial faults in the work held by Bienemann which could not be overcome by the next generations of historians: Firstly, he never made any indication on the origins of the published documents, so we know nothing at all about how he gained access to Parrot's collection, in what condition and extent he found it, and so on. Secondly, Bienemann published only his own translations of the letters (extracts or in full) in German, while all the original correspondence was in French. So this retranslation-regardless of the high quality-created a very 
substantial problem in the interpretation of this historical source. And indeed, already in 1895, some extracts from the correspondence appeared in Russian, in the historical magazine Russkaia Starina (Mardarev, 1895), but it was the translation from Bienemann's translation, which means that the original text was distorted twice and the unique style of the letters was completely lost or even misinterpreted.

What became of Parrot's collection after Bienemann? Again, our information is very limited but we know that in 1907 this collection entered the funds of manuscripts and museum objects gathered by the Society for History and Antiquities in Riga (Gesellschaft für Geschichte und Altertumskunde der Ostseeprovinzien Russlands zu Riga). This historical society founded the Dom Museum of Riga. It was situated in the complex of building of the Dom in Riga and one may speculate that Parrot's collection was also kept there until 1936, when the museum was transformed into another institution, and his documental belongings were delivered to the Latvian State Historical Archive (Latvijas Valsts vēstures arbìvs).

This archive exists until now, it includes the fund no. 7350, the personal archival fund of Georg Friedrich Parrot. But, according to the record of this fund, it is possible to follow its past only from 1958. A detailed analysis shows that the composition of this fund does not coincide with the original Parrot's collection of documents: one can easily reveal some lacunas due to the absence of concrete documents that figured in the original register made by Parrot and his daughter. It means that somebody at some historical moment after 1936 has removed several documents from Parrot's collection, and the questions remain-when, why and for what purpose? However, as the most amazing coincidence, the Latvian State Historical Archive today contains another fund, number 4060, which includes an archival collection obtained in 1979 from the Institute of History of the Latvian Academy of Sciences. This fund also includes four cases, about 70 archival sheets on the whole, which fill exactly in some lacunas in fund no. 7350 (LVVA, 1802-1806). ${ }^{3}$

Thus, an actual task for this research study lies in the following: to reconstruct the full composition of the correspondence between Parrot and Alexander I according to the sources held in the Latvian State Historical Archive, to resolve

3 Fund no. 4060 contains rough copies of several letters and accompanying notes by Parrot from 1802-1806. The reason why exactly these documents (selected seemingly without any system) turned out to be removed from the general collection of the fund no. 7350 is unknown. It is also not clear how they became part of the archive of the Institute of History of LAS. 
all the problems concerning its integrity or the possible losses in its present state and to prepare the content of letters for a complete edited publication, which was planned already by Parrot himself. Resolving this task can finally introduce this historical source of the highest rank into scientific use.

\section{Letters as an evidence of personal relations}

Although the audacious task mentioned above is very far from being done for the time being, there are some conclusions that can already be drawn on the basis of the general study of the letters as a whole. A general characteristic of the correspondence-the full volume of the letters, their quantitative dynamics, chronological development, and so on-can be given, which will lead to some observations on the personal relations of Parrot and Emperor Alexander I.

In sum, these letters embrace about 600 pages on the paper in quarto, written by Parrot in small and not very legible handwriting. They were divided by Parrot into 24 packages, and every package corresponds to a specific year, or sometimes to a part of a year. This does not mean that all the chronological attribution made by Parrot at the end of his life is correct, some letters are obviously wrongly dated, as observed already by Modest Korf. The period of the continuous correspondence includes the years from 1802 till 1812, then followed the isolated years of 1814 and 1816 and the final period from 1821 till 1825. It is important to emphasize that all the answers written by Alexander I date only to the period from 1802 till 1812. The greatest number of letters are from the years 1805 and 1807.

What strikes one most is that the letters exchanged between Parrot and Alexander I manifest the deepest feeling of confidence and friendly emotions, expressed by either of the correspondents. While the first letter of Alexander I, written to Parrot in August 1802, is still characterized by some formal features, being actually a response of the Russian Emperor to the Rector of the Dorpat University, very soon, already at the beginning of 1803 , any formality has disappeared from their correspondence. The style becomes very significant. The professor names his Emperor in no other way as "my beloved, my dear, the dearest of all the mortals, my Alexander". ${ }^{4}$ His signature is always the same- "Yours, Parrot", without any other expressions of courtesy, such as "Your humble servant", and so on: those formulas were never used by Parrot, as if he liked to stress here

"Mon bien aimé, mon cher, le plus cher des mortels, mon ami, mon Alexandre". 
the principal equality of both in their friendship. Alexander I also answered with no less emotion and devotion. For example, in 1803 he gave a response to Parrot's letter in which the latter insisted very ardently on their nearest appointment; so Alexander I wrote a long phrase where he reproached Parrot for his passionate temperament, which could injure the very soul of Alexander I, and then the Emperor stressed that he gave Parrot no reasons to doubt the sentiments regarding him. ${ }^{5}$ Alexander begged his friend to keep confidence and trust because their meeting would take place as soon as possible.

Further reading of Parrot's and Alexander's letters allows making a detailed reconstruction of the "dynamics" of their close relations. One can easily mark some crucial points and evaluate the highest degree of their mutual confidence. The latter could be weighted, for example, according to some advices which Parrot dared to give to Alexander I: on his behavior with Empress Elizabeth Alexeievna, with the other courtiers, about his time-table, and so on. In May 1803, Alexander trusted in his letter to Parrot an important personal secret, but demanded that he destroyed this letter after reading-Parrot has done this but he conserved the ashes which remained in a special envelope in the same collection together with other letters of Alexander I (LVVA, 1802-1825, no. 6, p. 29).

Of course, in addition to the personal aspects, their correspondence touched upon a very wide circle of questions about the different aspects of the inner and foreign policy of the Russian Empire. Many of the letters were in fact memoirs, forwarded by the Tsar to his ministers. These propositions considered the most topical problems of the Russian state, among them-the expected constitution, the liberation of peasants and elimination of serfdom, the development of public education (together with important questions on the administration of the universities of the Russian Empire), the finances, and the role of Russia in Europe during the period of Napoleonic wars.

These opinions of the professor from Dorpat were closely examined by Alexander I, often in their direct discussion during Parrot's visits to St. Petersburg. These visits became regular already since the middle of October 1802, when Parrot succeeded in securing the autonomy of the Dorpat University (for details see Andreev, 2009, pp. 383-388). From the whole collection of letters it is possible to determine that Parrot came to St. Petersburg three or four times each year

\footnotetext{
"Pourquoi être toujours si passioné, si prompt à vous désespérer? Un certain calme doit être inséparable de la fermeté et voudriez-vous en manquer? Il y a des choses sur lesquelles douter est l'équivalent de blesser; par quoi vous ai-je donné bien de douter de mes sentiments pour Vous? Et la confiance, ne doit-elle pas accompagner votre estime pour moi?"
} 
before 1807: formally these were visits related to the university affairs, but each time Parrot demanded a meeting with the Tsar which lasted usually for several hours (many letters dealt with the appointment of such meetings). So one may guess that many times the university problems were no more than a pretext for a chance to see his "beloved" monarch.

On the other hand, the questions dealing with the Dorpat University indeed occupied a significant place in the correspondence, and on many occasions Alexander I had a direct opportunity to make complaints against the university, which he did to Parrot with utmost accuracy and delicacy. For example, in 1805 the Emperor was seriously troubled by the student disorders, but he wrote it in his letter to Parrot in the lightest way he could, as if he would like to excuse his true indignation. ${ }^{6}$

Generally in the affairs concerning the Ministry of Public Education the Emperor felt a very strong pressure from Parrot, who tried to directly impose his own decisions to the administration of the Ministry. Alexander I mostly supported Parrot (or gave in to his pressure), but the Emperor did not want to manifest his position explicitly, as he thought it would break the common order of the affairs. So the Emperor himself sometimes tried to use some other official as his secret tool. Often such a role was played by the curator of the Dorpat University Friedrich Maximilian Klinger (1752-1831). ${ }^{7}$ For instance, in 1804 Alexander I wrote to Parrot: "It is urgent that you caution Klinger and communicate to him the Plan that you have presented to me in order that he would be absolutely on our side before the Minister will talk to him" ${ }^{8}$ It is remarkable that when trying to help Parrot in his official affairs, Alexander I (as the Russian autocrat!) did not use his power as an emperor but, on the contrary, wished to mask his influence, to hide himself and his will behind other high officials.

6 "Je suis ennemi declaré $d u$ desordre et voila tout", and in another letter: "cela passe toute permission et il m'est impossible de tolérer des choses pareilles".

7 The personality of the first Dorpat curator attracts a significant attention of historians: see a new study about Klinger's relations to Parrot in: Gavrilina, 2017.

8 "Il est urgent que Vous avertissiez Klinger et que Vous lui communiquiez le Plan, que Vous mavez presenté pour quil soit absolument dans notre sens, quand le ministre lui parlera". 


\section{Influence or illusion?}

The aforesaid leads to the final question - in what extent could one measure the real impact of Parrot on the reforms and other official deeds during the rule of Alexander I? Without any doubt it can be argued that Alexander I received all the letters of Parrot directly, and they were lying on the Emperor's desk-but did he give them any concrete use? It might seem that a direct answer could be derived from the response letters of Alexander I to Parrot, because if Alexander I indeed was influenced by Parrot's ideas and conceptions of reforms, he must have also expressed that in written form. However, in the particular case of their correspondence these expectations would be disappointing: one of the main characteristic of Alexander's answers to Parrot is that in his letters he hardly ever touched upon concrete problems or questions and instead only expressed his feelings, spirits, even intonations - and often it is impossible to tell in which connection it has been done. For the Emperor it was important to preserve the appearance of a warm friendship and cordial relations, but when the enforcement of Parrot's proposals would involve Alexander I colliding with the ministers, he always gave in or began to seek a compromise to avoid this collision (which was unacceptable for Parrot). Generally said, in almost all the issues touched upon with the Tsar by Parrot in his memoirs, with the exception of the field of public education, Alexander I directly put none of Parrot's ideas to use-even though he always was very grateful to the professor for his writings. So it was emotion rather than practice that always won.

On this emotional plane, the most difficult and complicated situation in the relationship between Alexander I and Parrot was related to the resignation of Mikhail Speransky (1772-1831) in March 1812, which was a great shock to Alexander I and caused him much anguish (Shilder, 1898, vol. 3, pp. 35-42). Parrot happened to come to St. Petersburg at the same moment-and served as a lightning rod for Alexander I. It is very characteristic that Alexander I would behave himself as if he needed advice from Parrot about what to do with Speransky, who was accused of high treason. Parrot's letter shows that the professor accepted and shared all the feelings of Alexander I on this occasion but he appealed to the Emperor to be merciful. So Parrot himself seemed to have influence on the decision about the fate of Speransky. ${ }^{9}$ Other sources, however, reveal that this

9 This letter, dated to 17 March 1812, the eve of Speransky's fall, was first published in 1898 by Nikolai Shilder, the Russian historian who compiled the official biography of Alexander I (Shilder, 1898, vol. 3, pp. 487-490). Evidently, Shilder gained some access to Parrot's papers at that time- probably through the agency of Friedrich Bienemann. 
decision was prepared and launched several days before the meeting between Parrot and Alexander I-so it was the words of consolation rather than the deeds that Alexander I needed from Parrot in that particular case, and probably in many others. Also, it is possible that since this last case was so dramatic and disturbing, Alexander I could not later resume his relations with Parrot—so this highest emotional point between Alexander I and Parrot in March 1812 was at the same time their last meeting.

In the following period of war with Napoleon and the Congress of Vienna, 1814-1815, Parrot and Alexander I had not many opportunities to see each other. But in 1816, when Parrot arrived to St. Petersburg with a special purpose to resume the former friendship, Alexander I did not respond to his many letters and short notes; he did not even write a word to the professor. Then Parrot, manifesting many emotions and sufferings on his side, announced a rupture of their relations. However he could not keep it for very long, because since 1821 he began to send again to the Emperor his memoirs with various proposals on university-related subjects and other themes. In 1823 he strongly insisted on their personal meeting, probably in the hope of renewing their former state of closeness.

By these years, however, Alexander I had moved very far in his internal and foreign policy from the liberal dreaming of the beginning of his rule. Russia had entered the time of Holy Alliance and reactionary activities in the field of public education were carried out by such figures as Mikhail Magnitskiy (1778-1844), against whom Parrot rose strongly with all his force. For the Russian Emperor in this period Parrot remained only a concerned witness of the principles according to which the Tsar had begun his rule-the principles that Alexander I could not return to. This is why Alexander I, having received more letters from Parrot practically until his very death, never replied to any of them.

As final remarks one should mention that Parrot tried to preserve his value as an "adviser of the Russian Tsar" already after the death of Alexander I, and in many regards he succeeded in doing that, because the next Russian Emperor, Nicolas I, also received letters from Parrot and took these into consideration during the whole extent of his rule, for about 30 years. ${ }^{10}$ But there was never even a shadow of personal relations between them: in fact, they never met in person in those 30 years, and all the answers that Parrot received from the Winter Palace were written not by the Tsar but by Count Alexander von Benckendorff

10 Contrarily to Parrot's original letters to Alexander I, his letters to Nicolas I have been preserved in full (together with a number of copies), held in GARF, f. 109 and f. 728. 
(1782-1844), chief of the Third Section of His Imperial Majesty's Own Chancellery. In spite of this lack (or probably owing to these circumstances) the connection between Parrot and Nicolas I was more fruitful from the practical point of view, and the most famous fruit of this connection appeared in Tartuthe so-called Professors' Institute of the University of Dorpat, which helped to bring up a whole new generation of professors for the universities of the Russian Empire (Andreev, 2009, p. 492).

Thus, the correspondence between Emperor Alexander I and Georg Friedrich Parrot is a very extensive and rich historical source which is still far from being fully introduced into scientific circulation. This correspondence is distinguished by a high degree of emotionality of both correspondents, which gives important new touches to the portrait of the personality of the Russian Emperor and his relationship with his closest friends. Professor Parrot broaches in his letters a very wide range of issues related to the foreign and domestic policy of the Russian Empire; in particular, much space is devoted to issues related to the development of public education and specifically to the University of Dorpat. However, a closer analysis of the relations between Alexander I and Parrot reveals how limited were the possibilities of a subject, even if invested with full confidence of the monarch, to do good on a wide scale, regarding the whole country. The very cause lies in the nature of autocracy as such, and in this autocracy even a primarily liberal and favorably disposed person, like Alexander I, could not fulfil his tasks to reform Russia and liberate its political and social system. Only minor changes or improvements were possible, as the example of the University of Dorpat shows, and already for that fact one must be very grateful to Professor Parrot.

\section{References}

Andreev, A. Iu. (2009), Rossiiskie universitety XVIII-pervoi poloviny XIX veka v kontekste universitetskoi istorii Evropy, Moscow: Znak.

Andreev, A. Iu. \& Tosato-Rigo, D. (2014), Imperator Aleksandr I i Frederik-Sezar Lagarp. Pisma. Dokumenty, vol. 1 (1782-1802), Moscow: Politicheskaia enciklopediia.

Andreev, A. Iu. \& Tosato-Rigo, D. (2017a), Imperator Aleksandr I i Frederik-Sezar Lagarp. Pisma. Dokumenty, vol. 2 (1802-1815), Moscow: Politicheskaia enciklopediia.

Andreev, A. Iu. \& Tosato-Rigo, D. (2017b), Imperator Aleksandr I i Frederik-Sezar Lagarp. Pisma. Dokumenty, vol. 3 (1815-1832), Moscow: Politicheskaia enciklopediia.

Arkhangelskii, A. N. (2012), Aleksandr I, Moscow: Molodaia gvardiia. 
Bienemann, F. (1894), 'Aus dem Briefwechsel Georg Friedrich Parrots mit Kaiser Alexander I,' in Deutsche Revue über das gesamte nationale Leben der Gegenwart, vol. 4, pp. 161-175, 318-336.

Bienemann, F. (1902), Der Dorpater Professor G. F. Parrot und Kaiser Alexander I, Reval: Kluge.

Diederichs, H. (1909), 'Friedrich Bienemann,' Aus baltischer Geistesarbeit, vol. 2, pp. 99-105.

Gavrilina, I. A. (2017), 'Rektor G. F. Parrot i popechitel F.M.Klinger: dva vzgliada na razvitie Derptskogo universiteta v pervye gody ego suschestvovaniia (1802-1803),' Klio, no. 10 , vol. 130 , pp. 47-56.

GARF (1855), Baron M. Korf's note on the papers of the deceased Professor Parrot, f. 728 (Collection of manuscripts from the library of the Winter Palace), op. 1, d. 2480, State Archive of the Russian Federation, Moscow.

Gracheva, Iu. E. (2012), “Pozvolte mne byt poleznym!” Vasilii Nazarovich Karazin na gosudarstvennoi sluzhbe i v obschestvennoi zhizni Rossii pervoi treti XIX v., Moscow: Izdatel'stvo Pravoslavnogo Sviato-Tikhonovskogo gumanitarnogo universiteta.

Hartley, J. M. (1994), Alexander I, London: Longman.

Korf, M. A. (1861), Zhizn' grafa M. M. Speranskogo, vols. 1-2, St. Petersburg: Imperatorskaia Publichnaia biblioteka.

LVVA (1802-1806), G. F. Parrot's letters and notes to Alexander I (rough copies), f. 4060, nos. 1081-1084, Institute of History of Latvian Academy of Science, Latvian State Historical Archives, Riga.

LVVA (1802-1825), Letters of Alexander I to G. F. Parrot, 1802-1812 (copies), Letters of G. F. Parrot to Alexander I (rough copies), 1802-1825, f. 7350 (Georg Friedrich Parrot), no. 6-9, Latvian State Historical Archive, Riga.

LVVA (1850s), Register of G. F. Parrot's letters to Alexander I, f. 7350 (Georg Friedrich Parrot), no. 5, Latvian State Historical Archive, Riga.

Mardarev, M. (1895), 'Pisma i zapiski Georga Fridrikha Parrota k imperatoram Aleksandru I i Nikolaiu I,' Russkaia starina, vol. 83, no. 4, pp. 191-219.

Rey, M.-P. (2009), Alexandre Ier, Paris: Flammarion.

RGADA (1824-1825), Letters of G. F. Parrot to Alexander I, Gosarkhiv, razriad XI, op. 1, d. 1163, Russian State Archive of Ancient Acts, Moscow.

RGIA (1803), G. F. Parrot's note to Alexander I, concerning the public school in the Livonia, f. 1101, op. 1, d. 236, Russian State Historical Archive, St. Petersburg.

RGIA (1855), On the request to publish the biography of G. F. Parrot, prepared by his daughter, the wife of State Councillor Storch, f. 772, op. 1, d. 3715, Russian State Historical Archive, St. Petersburg.

Safonov, M. M. (1988), Problema reform v pravitel'stvennoi politike Rossii na rubezhe XVIII I XIX vv., Leningrad: Nauka. 
Shilder, N. K. (1898), Imperator Aleksandr I: ego zhizn' $i$ tsarstvovanie, vols. 1-4, St. Petersburg: Suvorin.

Andrei lu. Andreev, D.Phil is a professor of modern history at the Lomonosov Moscow State University. His main research area is history of universities in the Russian Empire and in Europe, with an emphasis on international cultural and scientific relations. He has published several books in Russian, as well as articles in German, French and English in Jahrbuch für Universitätsgeschichte, Jahrbuch für Geschichte Osteuropas, Rossiiskaia istoria, Slovene, etc. 